\title{
Control of black rot disease in cabbage by integration of mulching, pruning and hot water treatment of seeds
}

\author{
Ombuna GJ ${ }^{1}$, Nyangeri $\mathrm{BJ}^{1}$ and Maobe $\mathrm{SN}^{2}$ \\ ${ }^{1}$ Faculty of Pure and Applied Sciences, Kisii University, 408-40200, Kisii-Kenya \\ ${ }^{2}$ Faculty of Agriculture and Natural Resources, Kisii University, 408-40200, Kisii-Kenya
}

Ombuna GJ, Nyangeri BJ, Maobe SN 2019 - Control of black rot disease in cabbage by integration of mulching, pruning and hot water treatment of seeds. Plant Pathology \& Quarantine 9(1), 23-29, Doi $10.5943 / \mathrm{ppq} / 9 / 1 / 3$

\begin{abstract}
Black rot disease of cabbage caused by Xanthomonas campestris pv. campestris has been a major hindering factor to cabbage production in Kisii County, Kenya. The conventional technique for controlling this disease has been the use of chemicals. However, this method of control has not been effective as the disease is seed borne. In addition, most chemicals pollute the environment and make it unconducive for the survival of other important organisms such as decomposers. In this paper, the integration of hot water treatment of seeds, mulching, pruning and plant debris management was considered as an approach that can effectively manage this disease. To achieve this objective, seeds of Gloria Hybrid cabbage were inoculated with a bacterial suspension of $X$. campestris pv. campestris isolated from leaf segments obtained from plant leaves with characteristics symptoms of black rot disease. A portion of the inoculated seeds were treated with hot water at $50^{\circ} \mathrm{C}$ for 25 minutes and later planted in the field to evaluate the effects of mulching, pruning and plant debris management on black rot disease. Another portion of the inoculated seeds were not treated with hot water and were planted to serve as a control. Disease was scored on a scale of 1-9 based on the length of the V-shaped lesions developed on the margin of plant leaves. The results obtained show that integration of hot water treatment of seeds, mulching, pruning and plant debris management led to $76.1 \%$ less black rot disease and a $78.3 \%$ increase in marketable yields. Hence such treatment is recommended as the best approach to manage black rot disease of cabbage in the field.
\end{abstract}

Key words - disease score - Gloria Hybrid - integration - severity - significant difference Xanthomonas campestris

\section{Introduction}

Black rot disease caused by Xanthomonas campestris pv. campestris is a worldwide problem causing serious damage to all crops of the Brassicaceae family and is of concern to both scientists and farmers (Ryan et al. 2011). According to Lo \& Wang (2001), Bila (2008), the loss caused by this disease on cabbage ranges from $30-70 \%$, depending on the prevailing weather conditions. In Kenya, the disease causes severe damage leading to total crop loss during the warm and wet seasons (Anonymous 2000, Varela et al. 2003, Otipa et al. 2013). Various control measures have been adopted both at the farm level and at research centers, but no one method controls the disease 
effectively (Celetti et al. 2002). Some of the practices currently employed by farmers to manage the disease include chemical control, host resistance, biological control, cultural practices and field sanitation.

Chemical control involves the use of sodium hypochlorite, hydrogen peroxide, hot cupric acetate or zinc sulfate to manage the disease (Williams 1980, Miller et al. 1996). Unfortunately, most of the chemicals being used to control black rot disease of cabbage have low efficacies (Massomo et al. 2003, Bila et al. 2013) while others have not been approved. Although Actigard chemical induces resistance in some plants and is labelled for suppressing black rot on commercially grown crucifers, its results in cabbage has been disappointing (Seebold et al. 2008). Moreover, chemical treatment of seeds only disinfects the seed surface and does not kill the pathogens that are found inside the seed (Miller 2002). Copper fungicides previously used to spray cabbage plants were found to cause black spots on leaves and its use has since been outlawed (Averre 2000).

The development and use of black rot resistant cultivars has long been recognized as an important tool for disease control, though the practice has had limited success (Miller et al. 1996). This is because most of the local cultivars are highly susceptible (Massomo et al. 2003, Bila et al. 2013). The challenge of this approach is that some cultivars, which are partially resistant or tolerant to black rot (Seebold et al. 2008), are of poor quality (not sweet tasting) and thus not readily adopted by farmers. Furthermore, the source for major gene (durable) resistance in Brassica oleracea is rare and thus new strains of pathogens, capable of infecting resistant varieties may arise with time (Miller et al. 1996, Averre 2000, Seebold et al. 2008). The most common and potentially useful sources of black rot resistance occur in genomes of wild types of Brassica (Taylor et al. 2002). Unfortunately, transferring these genes into local cultivars may results in transfer of other undesirable genes such as poor taste (Acquaah 2007). Moreover, development of resistance cultivars takes a long time.

A few biocontrol agents antagonistic to Xanthomonas campestris pv. campestris have been isolated from various sources and are being used in the control of black rot of Brassica crops. Various strains of yeast (Sayonara et al. 1999, Celetti et al. 2002), a Paenibacillus isolate (Ghazalibiglar 2014), Bacillus strains (Massomo et al. 2003) and plant growth promoting Rhizobacteria (PGPR) such as Bacillus subtilis R14, B. pumilus C116, B. megaterium pv. cerealis RAB7 and $B$. cereus $\mathrm{C} 210$ have being identified as important biocontrol agents due to their antibiotic effect against $X$. campestris pv. campestris bacterium (Luna et al. 2002). However, the agrochemicals (fertilizers, pesticides, herbicides and insecticides) that farmers use create an unconducive environment for survival of the biocontrol agents (Huang 1997).

Cultural practices such as mulching (Hunter et al. 1975, Onsando 1992), planting disease-free seeds, maintaining proper field sanitation, elimination of infected plant debris, pruning, rouging of diseased plants, eradication of alternate hosts, and crop rotation have been identified as cultural practices that curb the spread of black rot disease as well as reducing, excluding and eliminating the initial sources of disease (Averre 2000, Smart \& Holly 2013). Timing irrigation when plants will dry quickly and restricting field activities until later in the day when fields are dry will help reduce disease spread (Celetti et al. 2002). However, this has not achieved much as the disease is seedborne (Williams 1980, Celetti et al. 2002). Use of disease-free seeds has not been achieved due to the fact that as few as three infected seeds in 10,000 (0.03\% seed infection) can cause black rot epidemics in a field (Celetti et al. 2002). Excessive treatment of seeds reduces the seed germination percentage and vigor. Crop rotation alone has not been effective in controlling black rot disease as infection can be introduced into the farms through infected seeds, surface run off and farm equipment carrying infested soils (Williams 1980, Celetti et al. 2002). In addition, the small sized farms found in Kisii County, due to overpopulation, have limited the practice of crop rotation.

\section{Materials \& Methods}

Samples of infected leaves of cabbage were randomly picked from KALRO and ATC farms in Kisii County. Three leaves with symptoms characteristic of black rot disease were picked from 
randomly selected diseased plants along a transact line in the selected farms. These leaves were then mixed and a total of 10 leaves were randomly picked from the sample. The leaves were then placed in an open woven cotton bag inside a well ventilated box. The box was labelled and transported to the laboratory for isolation of $X$. campestris pv. campestris.

The cabbage leaves obtained from the field were washed in running tap water and air-dried at room temperature $\left(27^{\circ} \mathrm{C}\right)$. The dried leaves were placed in $1 \%$ tween-20 solution to wet them. The leaves were then placed in $10 \%$ sodium hypochlorite solution for 5 minutes to disinfect them after which they were rinsed five times using sterile distilled water and then air-dried on a clean disinfected bench. Leaf segments measuring $2 \times 3 \mathrm{~mm}$ were excised from the lesion margins of the dried and sterilized leaves. The leaf segments were placed in a $50 \mathrm{ml}$ beaker containing $0.85 \%$ sterile saline $(\mathrm{NaCl})$ solution and left to stand for 15 minutes in a lamina air-flow chamber to allow the bacteria to ooze out of the plant tissues into the saline solution. The leaf tissue segments were then removed.

Loopfuls of the saline solution were streaked on pre-chilled plates (at $-2^{\circ} \mathrm{C}$ to $-4^{\circ} \mathrm{C}$ ) containing nutrient agar. Saprophytic and antagonistic bacteria associated with crucifer tissues grow at a faster rate and prevent the growth of $X$. campestris pv. campestris. Thus, to prevent their growth $10 \mathrm{mg} / \mathrm{ml}$ of nitrofurantoin and $0.5 \mathrm{mg} / \mathrm{ml}$ vancomycin were added to the nutrient agar medium. The plates were then incubated for 48 hours at $28^{\circ} \mathrm{C}$ after which they were inspected for the presence of pale yellowish and convex mucoid bacterial colonies. Colonies were subcultured on yeast dextrose, calcium carbonate (YDC) agar to purify bacterial colonies. The purified colonies were stored at on porcelain beads in Protect tubes maintained on nutrient agar at $25^{\circ} \mathrm{C}$. Cultural characteristics such as the yellowish and convex mucoid colonies, staining characteristics and pathogenicity tests were used to identify the bacterium as $X$. campestris pv. campestris.

Relatively clean seeds of Gloria Hybrid seeds were obtained from the Kenya seed company. A $100 \mathrm{ml}$ suspension of the field bacterial isolates (at a concentration of $10^{4} \mathrm{CFU} / \mathrm{ml}$ ) was prepared in $0.85 \%$ saline solution. About 50 grams of seeds (10,000 seeds) of Gloria Hybrid were immersed in the cell suspension. The contents were shaken at 125 r.p.m at $25^{\circ} \mathrm{C}$ for 5 minutes. The liquid was removed with a pipette and the seeds spread on blotting paper to dry overnight in a Bio-Safety cabinet.

The inoculated seeds were divided into two equal portions. The first portion (labelled as $\mathrm{I}_{0}$ ) was established in a greenhouse nursery bed without any further treatment to serve as the control. The second portion of inoculated seeds was labeled as $\mathrm{I}_{1}$. These seeds were subjected to hot water treatment at $50^{\circ} \mathrm{C}$ for 25 minutes using the ISTA standard procedures of Miller et al. (2005) before being established in greenhouse nursery beds. All seedlings in the greenhouse were transplanted to the field at the age of 4 weeks. In the field, seedlings were established in a complete randomized block design of four replicas. The $\mathrm{I}_{1}$ seedlings were further subjected to mulching and pruning with all the other field operation practices being carried out as per the recommended standards in cabbage production. This experiment was repeated in two different seasons of 2017.

Disease scoring, on a scale of 1-9, was done on the basis of the level of disease symptoms, which was based on the length of the $\mathrm{V}$-shaped lesions developing on the cabbage leaves. The length of $\mathrm{V}$-shaped lesions, measured in centimeters from the leaf margin inwards, provided the disease score (Table 1). This was done on a weekly basis after crop establishment in the field after transplantation.

\section{Results}

In order to ascertain the effect of integrating hot water treatment of seeds, mulching and pruning on black rot disease of cabbage, eight observations were made, which included disease mean scores for integration season 1, no integration season 1, integration season 2, no integration season 2. Disease means scores for integration and no integration across season 1, season 2 and across the seasons are shown in Table 2. 
Table 1 Disease score rates

\begin{tabular}{lc}
\hline Length of V-shaped lesion & Score rates \\
\hline$<0.5 \mathrm{~cm}$ & 1 \\
$>0.5-1.0 \mathrm{~cm}$ & 2 \\
$>1.0-1.5 \mathrm{~cm}$ & 3 \\
$>1.5-2.0 \mathrm{~cm}$ & 4 \\
$>2.0-3.0 \mathrm{~cm}$ & 5 \\
$>3.0-4.0 \mathrm{~cm}$ & 6 \\
$>4.0-5.0 \mathrm{~cm}$ & 7 \\
$>5.0-6.0 \mathrm{~cm}$ & 8 \\
$>6.0 \mathrm{~cm}$ to plant death & 9 \\
\hline
\end{tabular}

Table 2 Disease mean score for integration across seasons

\begin{tabular}{lllll}
\hline $\begin{array}{l}\text { Weeks after crop } \\
\text { establishment }\end{array}$ & $\mathbf{S}_{\mathbf{1}} \mathbf{I}_{\mathbf{1}}$ & $\mathbf{S}_{\mathbf{1}} \mathbf{I}_{\mathbf{0}}$ & $\mathbf{S}_{\mathbf{2}} \mathbf{I}_{\mathbf{1}}$ & $\mathbf{S}_{\mathbf{2}} \mathbf{I}_{\mathbf{0}}$ \\
\hline 7 & & & $2.75 \mathrm{a}$ & $7.625 \mathrm{a}$ \\
6 & & & $2.625 \mathrm{ab}$ & $7.25 \mathrm{~b}$ \\
5 & & & $2.625 \mathrm{ab}$ & $5.875 \mathrm{c}$ \\
4 & $3.00 \mathrm{a}$ & $7.50 \mathrm{a}$ & $2.625 \mathrm{bc}$ & $5.75 \mathrm{c}$ \\
3 & $2.625 \mathrm{a}$ & $7.125 \mathrm{a}$ & $1.875 \mathrm{~cd}$ & $5.75 \mathrm{bc}$ \\
2 & $1.25 \mathrm{~b}$ & $4.75 \mathrm{~b}$ & $1.625 \mathrm{de}$ & $5.0 \mathrm{~d}$ \\
1 & $1.00 \mathrm{~b}$ & $2.663 \mathrm{c}$ & $1.375 \mathrm{e}$ & $3.0 \mathrm{e}$ \\
Mean & 1.969 & 5.500 & 2.161 & 5.750 \\
SE & 0.1398 & 0.184 & 0.1308 & 0.1157 \\
CV \% & 20 & 9 & 17 & 6 \\
P-value & $<0.0001$ & $<0.0001$ & $<0.0001$ & $<0.0001$ \\
\hline
\end{tabular}

Means figures in the column with different letters are significantly different $(\mathrm{p}<0.05)$, where $\mathrm{S}_{1} \mathrm{I}_{1}$ is the disease mean score for season 1 integration, $S_{1} I_{0}$ is the disease mean score for season 1 no integration, $S_{2} I_{1}$ is the disease mean score for season 2 integration, and $S_{2} I_{0}$ is the disease mean score for season 2 no integration.

The scores generally increased with time. There was evidence of significant difference between the times, for example, the score was high (7.625) after 7 weeks compared to after 1 week (3.0) in season 2 where integration was not done. In season 1 the scores were also high at 4 weeks (7.50) as compared to 1 week (2.663) in cases where integration was not done. The score was generally higher in cases where integration was not done compared to cases where integration was done throughout both seasons. Table 3 shows disease mean score for season 1, season 2 and across the seasons.

Table 3 Disease mean score for integration

\begin{tabular}{llll}
\hline Treatment & Season 1 & Season 2 & Across Seasons \\
\hline No integration & $5.500 \mathrm{a}$ & $5.750 \mathrm{a}$ & $5.659 \mathrm{a}$ \\
Integration & $1.375 \mathrm{~b}$ & $1.339 \mathrm{~b}$ & $1.352 \mathrm{~b}$ \\
S.E. \pm & 0.118 & 0.042 & \\
CV\% & 19 & 9 & 13 \\
P-value & $<0.0001$ & $<0.0001$ & $<0.0001$ \\
\hline
\end{tabular}

Means figures in the column with different letters are significantly different $(\mathrm{p}<0.05)$.

This result shows that there was significant difference between the use of integration and no integration within seasons and across seasons. For instance, there was significantly high scores 
(5.659) where integration was not used as compared to where integration was used (1.352) across the seasons. A similar trend was observed in seasons 1 and 2. Table 4 shows the effect of integration on black rot disease in terms of percentage disease control.

Table 4 Effects of integration on black rot disease (in percentage disease control)

\begin{tabular}{llllll}
\hline Treatments & Score & $\begin{array}{l}\text { Disease } \\
\text { control }(\%)\end{array}$ & $\begin{array}{l}\text { Cabbage } \\
\text { mean weight } \\
\text { (kg/head) }\end{array}$ & $\begin{array}{l}\text { Marketable } \\
\text { yield } \\
\text { (tons/ha) }\end{array}$ & $\begin{array}{l}\text { Yield } \\
\text { increase } \\
(\%)\end{array}$ \\
\hline Integration $\left(\mathrm{I}_{1}\right)$ & $1.353 \mathrm{a}$ & 76.1 & $3.250 \mathrm{a}$ & $94.791 \mathrm{a}$ & 78.30 \\
Control $\left(\mathrm{I}_{0}\right)$ & $5.659 \mathrm{~b}$ & & $1.823 \mathrm{~b}$ & $53.163 \mathrm{~b}$ & - \\
S. E. & 0.123 & & 0.038 & 1.112 & \\
CV \% & 42 & & 5.94 & 5.94 & \\
P-value & $<0.0001$ & & $<0.0001$ & $<0.0001$ & \\
\hline
\end{tabular}

Means figures in the column with different letters are significantly different $(\mathrm{p}<0.05)$.

There was evidence of significant difference between $\mathrm{I}_{1}$ and $\mathrm{I}_{0}$. Treatment $\mathrm{I}_{1}$ (which is integration of hot water treatment of seeds, mulching and pruning) had a score of 1.353. On the other hand, $\mathrm{I}_{0}$ (control) had a disease mean score of 5.659.

The study findings show that at $76.1 \%$ disease control, integration had great impacts on black rot disease as far as its control is concerned. Fig. 1a shows the resultant plants from a field where integration was done while $1 \mathrm{~b}$ gives the plants from a field where integration was not done.

There was severe disease where integration was not done as compared to fields where integration of hot water treatment of seeds, mulching and pruning was carried out. Without integration many plants died while the remaining plants showed servere symptoms of black rot disease (Fig. 1b).

There was significant difference between yields from the cabbage that received treatment and those that never received any treatment (Table 4). Cabbage heads from fields with integration had significantly higher mean weight $(3.25 \mathrm{~kg})$ as compared to heads from the control $(1.823 \mathrm{~kg})$. A similar trend was observed in terms of marketable yields whereby integration had significantly $(\mathrm{p}<0.05)$ higher marketable yields $(94.791$ tons/ha) as compared to control $(53.163$ tons/ha $)$.
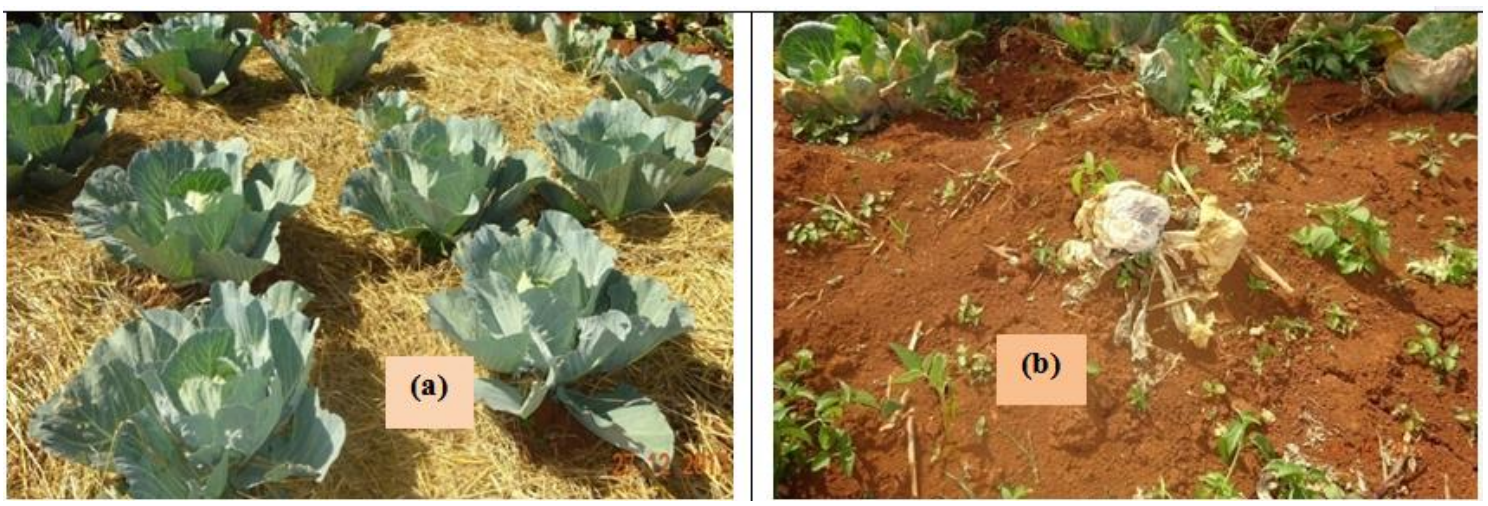

Fig. 1 - a Resultant plants from a field where integration was done. b Resultant plants from a field where integration was not done.

\section{Discussion}

This research sought to ascertain the effect of integrating hot water treatments of seeds, mulching and pruning on the control of black rot disease of cabbage. From the research findings, there was significant difference between integration and no integration. Treatment $\mathrm{I}_{1}$ had a disease mean score of 1.353 while $\mathrm{I}_{0}$, (control) had a score of 5.659 . 
The results clearly show that there was evidence of significant difference between where there was integration and no integration. There was a general increase in disease score with time in both seasons 1 and 2. The disease was less severe where integration of hot water treatment of seeds, mulching and pruning was done as compared to where no integration was done. A similar trend was observed in both seasons.

Mulching helped to prevent the spread of disease from the soil to plant leaves through rain splash as well as conserving moisture in the soil. On the other hand, pruning reduced the population of the pathogen in the plants, thus reducing disease spread among the plants. Removal of plant debris from the farm reduced the amount of pathogen present while maintaining field hygiene thus reducing the rate of crop infection. Integrating hot water treatment of seeds, mulching, pruning and proper management of plant debris reduced the severity of black rot disease by $76.1 \%$ in fields of cabbage plants. This effect on black rot disease control by integration resulted in higher yields from fields with integration as compared to fields that did not receive any treatment. Cabbage heads from fields with integration had significantly higher mean weight $(3.25 \mathrm{~kg})$ as compared to heads from the control $(1.823 \mathrm{~kg})$. Similarly, the marketable yields of 94.791 tons/ha from fields with integration was significantly higher as compared to marketable yields from the control (53.163 tons/ha).

\section{Acknowledgements}

We wish to acknowledge the Kenya Agricultural and Livestock Research Organization (KALRO) center, Kisii branch for allowing us space in their land and laboratory for this research.

\section{References}

Acquaah G. 2007 - Principles of Plant Genetics and Breeding, $1^{\text {st }}$ edition. Blackwell Publishing, Oxford, UK. p319-326.

Anonymous. 2000 - Plant Protection Manual for Selected Vegetables: French beans, Brassicas and Tomatoes. GTZ/ICIPE CD-ROM. Nairobi, Kenya.

Averre WC. 2000 - Black Rot of Cabbage and Related Crops. Vegetable Disease Information Note 16 (VDIN 0016). North Carolina Extension Service Publisher, North Carolina State University at Raleigh.

Bila J. 2008 - Status of Bacterial Black rot of Brassicas in Southern Region of Mozambique: Survey, Detection and Identification of the Causal Agent Xanthomonas campestris pv. campestris. M.Sc. thesis, University of Copenhagen, Denmark p102.

Bila J, Mortensen CN, Andresen M, Vicente JG, Wulff EG. 2013 - Xanthomonas campestris pv. campestris Race 1 is the main causal agent of black rot of Brassicas in Southern Mozambique. African Journal of Biotechnology 12(26), 602-610.

Celetti M, Kristen C. 2002 - Black Rot of Crucifer Crops. Ministry of Agriculture, Food and Rural Affairs. Ontario State.

Ghazalibiglar H. 2014 - Biocontrol of Black rot of Brassicas. Lincoln University.

Huang HHC. 1997 - Biological control of soil-borne diseases in Canada, In: International Symposium on Clean Agriculture, Sapporo, OECD. 52-59.

Hunter JE, Abawi GS, Becker RF. 1975 - Observation on the source and spread of Xanthomonas campestris in epidemic of black rot in New York. Plant Disease Reporter 59, 384-387.

Lo CT and Wang KM. 2001 - Inoculum sources of black rot of wasabi, caused by Phoma wasabiae. Plant Pathology Bulletin 10, 88-92.

Luna LC, Mariaono RLR, Souto-Mairo MA. 2002 - Production of a biocontrol agent for crucifers' black rot disease. Brazilian Journal of Chemical Engineering 19(2), 133-140.

Massomo SMS, Mabagala RB, Swai IS, Hockenhull J, Mortensen CN. 2003 - Evaluation of varietal resistance in cabbage against the black rot pathogen, Xanthomonas campestris pv.campestris in Tanzania. Crop Protection 23(4), 315-325. 
Miller SA. 2002 - Disease management for conventional and tomato growers. New York State Vegetable Conference and Berry Growers Meeting Proceedings, 193-194.

Miller SA, Lewis IML. 2005 - Hot water treatment of vegetable seeds to eradicate bacterial plant pathogens in organic production systems. Plant Pathology Extension Fact Sheet HYG-308605. The Ohio State University.

Miller SA, Sahin F, Rowe CR. 1996 - Black rot of crucifers. Extension fact sheet HYG-3125-96. The Ohio State University.

Onsando JM. 1992 - Black rot of Crucifers. In: Chaube HS, Singh US, Mukhopadyay AN, Kumar J. (eds) Plant Diseases of International Importance. Diseases of Vegetables and Oil Seed Crops (pp. 243-252) Prentice Hall, Englewood Cliffs, New Jersey, United States of America.

Otipa M, Kamau R, Gekone M. 2013 - Pest management decision guide: green and yellow list. Black rot disease- Plantwise. East African pest management innovation lab. The Ohio State University, College of food, Agriculture and Environmental Sciences.

Ryan RP, Vorhölter FJ, Potnis N, Jones JB et al. 2011 - Pathogenomics of Xanthomonas: understanding bacterium-plant interactions. Nature Reviews Microbiology 9, 344-355.

Sayonara MP, Mariano RLR, Sami JM, Gil Silva, Elizabeth AAM. 1999 - Antagonism of yeasts to Xanthomonas campestris pv. campestris on cabbage phylloplane in field. Journal of Microbiology 30(3), 375-379.

Seebold K, Bachi P, Beale J. 2008 - Black rot of crucifers. UK Cooperative Extension Service. University of Kentucky-College of Agriculture.

Smart DC and Holly WL. 2013 - Managing Black Rot of Cabbage and other Crucifer Crops in Organic Farming Systems. Cornell University.

Taylor JD, Conway J, Roberts SJ, Vicente JG. 2002 - Sources and origin of resistance to Xanthomonas campestris pv. campestris in Brassica genomes. Phytopathology 92, 105-111.

Varela AM, Seif AA, Lohr B. 2003 - A guide to Integrated Pest Management in Brassicas production in Eastern and Southern Africa. ICIPE, Nairobi Kenya.

Williams PH. - 1980 Black rot: a continuing threat to world crucifers. Plant Disease 64(8), 736742. 